\title{
Podridão apical do tomate, queima dos bordos das folhas de alface $e$ depressão amarga dos frutos em maçã: deficiência de Ca?
}

\author{
Paulo Cezar Rezende Fontes \\ Depto. Fitotecnia, UFV, 36571-000 Viçosa-MG; E-mail: pacerefo@ufv.br
}

Palavras-chave: Lycopersicon esculentum, Lactuca sativa, podridão apical, queima dos bordos, depressão amarga, cálcio, estresse.

Keywords: Lycopersicon esculentum, Lactuca sativa, blossom-end rot, tipburn, bitter pit, calcium, stress.

(Recebido para publicação em 13 de setembro de 2002 e aceito em 11 de outubro de 2002)

\begin{abstract}
A podridão apical do tomate (PA) é caracterizada pelo aparecimento de tecido necrótico na parte distal do fruto. Geralmente, ocorre nas primeiras semanas após a antese. Há cerca de 106 anos, a PA do tomate foi identificada como uma desordem fisiológica e há 60 anos é chamada de desordem relacionada à deficiência de cálcio (Saure, 2000). Apesar de intensamente estudada nos últimos 100 anos, a PA não é ainda completamente entendida (Adams \& Ho, 1995).
\end{abstract}

Recentemente, Nonami et al. (1995) propuseram que a PA não é diretamente causada pela deficiência de cálcio mas o resultado da expressão de algum gene em condições de estresse. Apesar dos progressos no entendimento da PA, ainda é pouco conhecido porque cultivares diferem na suscetibilidade e determinadas práticas culturais e condições ambientais predispõe o tomateiro à desordem (Kinet \& Peet, 1997). Consequentemente, medidas de controle a nível prático não são sempre eficazes.

Interações entre irradiação, temperatura, disponibilidade de água, características físicas do solo, salinidade, balanço catiônico na solução do solo, resíduos no solo, umidade relativa do ar, entre outros, controlam o aparecimento de PA nos frutos. Saure (2000) pergunta: a PA do tomate é uma desordem relacionada a cálcio ou a estresse? e propõe que a anomalia não é causada por um simples fator, mas por pelo menos dois eventos, em série:

1) maior suscetibilidade a diversos estresses devido ao aumento na concentração de giberelina, resultando em acentuado decréscimo na concentração de $\mathrm{Ca}$, causando aumento na permeabilidade das membranas celulares;

2) ocorrência de algum estresse acima de determinada intensidade (déficit hídrico, altas concentrações salinas ou de
$\mathrm{NH} 4^{+}$, alta temperatura, ...) que provocará a deterioração das membranas das células do fruto, principalmente os recém formados, com subseqüente perda de turgor e vazamento do líquido celular.

Explicação parecida para a ocorrência de depressão amarga dos frutos de maçã (bitter pit), tida como deficiência de cálcio, é proposta por Saure (2002). Também, a queima dos bordos das folhas ou tipburn da alface é uma desordem relacionada à deficiência de cálcio localizada nas margens da folha (Barta \& Tibbits, 2000), conceito não totalmente compartilhado por Saure (1998).

Nem o suprimento de Ca ao solo ou pulverizações com Ca são meios seguros de prevenir a ocorrência da queima dos bordos das folhas da alface, em lavouras na Alemanha (Wissemeir \& Zuhlke, 2002). Segundo os autores, mesmo cultivares tidas como tolerantes, inesperadamente e sem possibilidade de previsão, mostram sintomas da anomalia. E, das variáveis climáticas estudadas, apenas a irradiação, medida 3-4 semanas antes da colheita, relacionou-se, significativamente, com a incidência da queima das pontas, ainda com baixa predibilidade $(r=0,484)$.

Embora seja útil e operacionalmente fácil, parece não ser oportuno e aconselhável considerar a deficiência de Ca no fruto de tomate ou na folha de alface a causa independente da PAe da queima dos bordos e, menos ainda aconselhável, estuda-las utilizando o Ca como fator único. Da mesma forma, devido aos diversos processos envolvidos na produção de tomate e de alface, afetados diferentemente por condições ambientais específicas, é mais importante otimizar as condições edafo-climáticas e a quantidade dos insumos que maximizar a quantidade destes.

Assim, práticas culturais ou estratégias anti-estressantes como adequadas condições no solo para crescimento da raiz; suprimento balanceado de nutrientes, principalmente do nitrogênio; baixa salinidade na rizosfera; suprimento apropriado de água; plantio em condição de temperaturas amenas são exemplos de procedimentos, difíceis de serem otimizados, mas que, praticamente, resultam em ausência de PA em cultivar "tolerante" e, talvez, da queima dos bordos das folhas em alface.

\section{LITERATURA CITADA}

ADAMS, P.; HO, L.C. Uptake and distribution of nutrients in relation to tomato fruit quality. Acta Horticulturae, n. 412, p. 374-387.1995.

BARTA， D.J.; TIBBITS, T.W. Calcium localization and tipburn development in lettuce leaves during early enlargement. Journal American Society Horticultural Science, v. 125, p. 294-298. 2000.

KINET, J.M.; PEET, M.M. Tomato. In: Wien, H.C. (Ed.). The physiology of vegetable crops. $\mathrm{CAB}$ International, Wallingford, UK, p. $207-258.1997$. NONAMI, H.T.; FUKUYAMA, T.; YAMAMOTO, M.; LANG, L.; HASHIMOTO, Y.; ITO, T.; TOGNONI, F.; NAMIKI, T.; NUKAYA, A.; MARUO, T. Blossom-end rot of tomato plants may not be directly caused by calcium deficiency. Acta Horticulturae, n. 396, p. 107-114. 1995.

SAURE, M.C. Causes of the tipburn disorder in leaves of vegetables. Scientiae Horticulturae, v. 76, p. 131-147. 1998.

SAURE, M.C. Review. Blossom-end rot of tomato (Lycopersicon esculentum Mill) - a calcium - or a stess-related disorder? Scientia Horticulturae, v. 90, p. 193-208. 2001.

SAURE, M.C. Calciums spritzungen zur bekämpfung von Stippigkeit beim Apfel in heutiger sicht. Erwerbsobstbau, v. 44, p. 8-12. 2002.

WISSEMEIER, A.H.; ZUHLKE, G. Relation between climatic variables, growth and the incidence of tipburn in field-grown lettuce as evaluated by simple, partial and multiple regression analysis. Scientia Horticulturae, v. 93, p. 193-204. 2002. 